\title{
Epidemiology of malocclusions in primary dentition and associated factors
}

\section{Epidemiologia das más oclusões na dentição decídua e fatores associados}

\author{
Catiara Terra da Costa* \\ Miguel Roberto Simões Régio** \\ Ana Regina Romano ${ }^{* * *}$ \\ Dione Dias Torriani (in memorian) ${ }^{* * *}$ \\ Flávia Prietsch Wendt ${ }^{* * * *}$ \\ Maria Laura Menezes Bonow ${ }^{* * *}$
}

\section{Abstract}

Objective: this study aimed to evaluate malocclusion occurrence in children with complete primary dentition, describing the most frequent one and verifying potential associations with demographic, socioeconomic, and behavioral variables. Subjects and method: 502 children with complete primary dentition from primary schools in the city of Pelotas, RS, Brazil, were examined. Data was collected based on questionnaires distributed to the mothers, as well as on physical examinations of the oral cavity. The children with malocclusion presented at least one of the following changes: anterior open bite, deep overbite, posterior crossbite, and overjet. Chi-square tests for heterogeneity and linear trend were used to verify associations with demographic, socioeconomic, and behavioral variables. Results: the occurrence of malocclusions in the population studied was $67.5 \%$. From them, $33.6 \%$ presented anterior open bite, $22.3 \%$ presented deep overbite, $9.8 \%$ presented posterior crossbite, and overjet was present in $1.8 \%$. The most frequent malocclusion was anterior open bite, which was directly associated with the use of pacifier $(p<0.001)$, duration of use $(p<0.001)$, and frequency use $(p<0.001)$. There was also an inverse association with children's age $(p=0.007)$ and maternal level of education $(p=0.016)$. An association was found between the number of children and anterior open bite $(p=0.039)$. Conclusion: the population studied presented high prevalence of malocclusions, and anterior open bite was the most frequent one, which was associated with the use of pacifier, as well as the duration and frequency of use.

Keywords: Malocclusion. Dentition. Epidemiology.

\section{Introduction}

Malocclusions are described as developmental disorders of the craniofacial complex, which affect jaw, tongue, and facial muscles and result from an interaction of factors associated with genetics and the environment, causing changes in dental and facial aesthetics, as well as functional changes ${ }^{1}$.

Face and dentition reflect an individual's most intimate expression such as elaborating speech and communicating; they also play a role in respiratory, masticatory, and swallowing functions. Malocclusions may cause psychosocial problems, especially concerning aesthetics ${ }^{2}$, which is highly valued in current society in both personal and professional levels, lowering self-esteem and triggering a negative impact on the quality of life of children ${ }^{3}$.

Identifying the etiology of malocclusions is essential for the success of any orthodontic procedure. Anthropological studies have shown changes in occlusal patterns of the population, most likely caused by softer foods in their dietary habits, non-nutritive sucking habits such as the use of pacifier and thumb sucking, respiratory problems, and early weaning. ${ }^{4-6}$ Thus, the alleged increase in malocclusion indexes between primary, mixed, and permanent dentition is considered. ${ }^{7}$ In addition, extensive untreated caries lesions and premature primary tooth loss contribute to compromising the occlusion of children, ranking malocclusions third in the scale of oral health problem priorities..$^{4,5,7}$

Dentist, Orthodontic and Facial Orthopedic specialist, Master's in Pediatric Dentistry at the Dentistry School of Pelotas Federal University. Pelotas, RS, Brazil.

PhD in Dentistry, Professor of the Social and Preventive Dentistry Department at the Dentistry School of Pelotas Federal University. Pelotas, RS, Brazil.

${ }^{* *}$ PhD in Pediatric Dentistry, Professor of the Social and Preventive Dentistry Department at the Dentistry School of Pelotas Federal University. Pelotas, RS, Brazil.

${ }^{* * * *}$ Dentist, Master's in Pediatric Dentistry at the Dentistry School of Pelotas Federal University. Pelotas, RS, Brazil. 
Considering the changes caused by modern living conditions and the consequent development of certain types of malocclusion, several studies prove the occurrence of malocclusion in the young population. ${ }^{4,5,7-10}$ However, data referring to primary dentition are rare in Brazil and originate from studies of distinct focus, making comparability difficult.

Understanding the oral health conditions of children through epidemiological studies is fundamental for the development of adequate action proposals that may reduce the incidence of occlusion abnormality. This knowledge may also contribute to an ultimate evaluation of the impact of these actions. ${ }^{4,7}$ Regarding population, prevention is an attractive and viable alternative for the treatment of occlusal changes, considering there is the possibility of controlling environmental variables that contribute to its occurrence. ${ }^{5}$ Moreover, prevention simplifies or even avoids corrective orthodontic treatments, which are often inaccessible to the majority of the population.

Thus, the present study aims to evaluate the occurrence of malocclusions in primary dentition, verify the most prevalent malocclusion in children from both public and private schools in the city of Pelotas, RS, Brazil, and investigate its ultimate association with demographic, socioeconomic, and behavioral variables.

\section{Subjects and method}

This epidemiological study consisted of an evaluation of the oral health condition of the child population in the city of Pelotas, RS, Brazil, estimating caries prevalence, dental trauma, malocclusions, and associated factors. The research project was submitted to and approved by the Research Ethics Committee of the Dentistry School of the Federal University of Pelotas (021/2006). Parents that agreed on their children's participation signed an Informed Consent Form. This is a cutout of the aforementioned study, focusing specifically on malocclusions and associated factors.

For sample size calculation, the Epi Info 6.0 software (Centers for Disease Control and Prevention, Atlanta, Georgia, USA) was used, considering a $50 \%$ malocclusion occurrence in primary dentition, ${ }^{7}$ an acceptable 5\% error, and a 95\% confidence level. The sample size consisted of 306 children. To this number, another $10 \%$ was added to account for eventual losses and refusals, and another 15\% to enable a stratified analysis, resulting in a total sample of 387 children. A larger sample was effectively studied because of the interest in studying malocclusion-related factors. The final sample for malocclusion analysis had 502 children of both genders with complete primary dentition, and enrolled in both public and private schools in the city of Pelotas, RS, Brazil.
A list of children's schools in the city, provided by the City Hall, was stratified by school type - private and public - and 1/3 of each type of school was selected, resulting in 12 private and 8 public schools, based on proportionality. The schools participating in the study were randomly selected within each category. Every child examined was within the selected age group (from 2 to 5 years old, presenting complete dentition, no permanent teeth, and no previous orthodontic treatment), enrolled in the selected schools, and had previous consent of their parents.

The occlusal condition of children was evaluated by means of a visual examination performed by three teams that included an examiner (dentist) - a graduate student with a Master's in Pediatric Dentistry by the Dentistry School of the Federal University of Pelotas (UFPel), and a note taker - a Dentistry graduate student from the same institution, both previously trained and calibrated. The examiners obtained 0.81 Kappa coefficient agreement before starting the research. During data collection, $5 \%$ of the sample was reexamined, following the recommendations of the World Health Organization (WHO), ${ }^{11}$ in order to evaluate intra-examiner agreement, which amounted to 0.85 .

The visual inspection of the children's oral cavity was performed in the school facilities under natural light, following the biosafety recommendations of the WHO. ${ }^{11}$ The children were seated on a school chair with their heads leaning back, facing the source of natural light and the examiner sat opposite the child with a dental gauze and a wooden spatula. The note taker stood a meter away facing the examiner, allowing correct data recording and the visualization of the procedure. Data obtained from the physical examination and the identification information of children were written down on a clinical chart. The physical examination recorded aspects of anterior open bite, deep overbite, overjet, and crossbite. The criterion used for diagnosing occlusion was based on findings by Foster and Hamilton. ${ }^{12}$

Ideal overbite was the incisal tip of lower central primary incisors contacting the palatal surfaces of upper central primary incisors. Anterior open bite was the incisal tip of lower central primary incisors below the level of the incisal tip of upper central primary incisors, and deep overbite was the incisal tip of lower central primary incisors touching the palate. Ideal overjet was a positive incisor not exceeding $2 \mathrm{~mm}$ and posterior crossbite was the change recorded when upper primary molars occluded in lingual relationship to lower primary molars in centric occlusion.

The preschool children who presented at least one of these conditions were classified with malocclusion and those with none of these conditions were considered normal.

Sequentially, a pre-tested questionnaire (Figure 1) was sent to the children's mothers, including 
information referring to the following variables: demographic - child's age and gender, socioeconomic - type of school, family income, and maternal level of education, and behavioral - type of lacteal feeding and non-nutritive sucking habits. At the end of the research, parents received information on their child's examination and oral health.

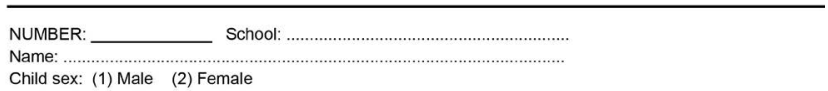

Child sex: (1) Male

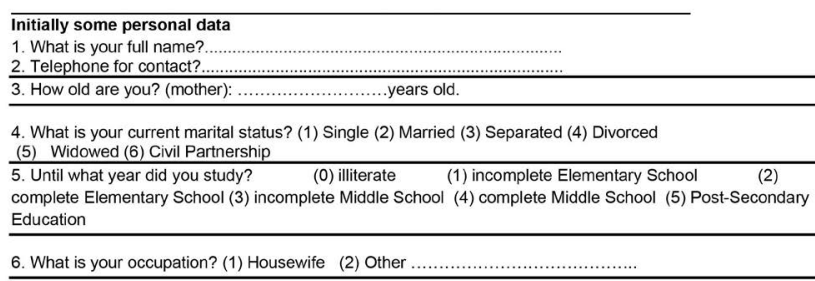

Now, some questions about your child and your family. Remember that all answers will be used for the research and will not be released to anyone.

7 . How old is your child? years old

8 . What is the date of yours child's birth?

9 . He/she is your first child? (0)No (1)Yes. IF YES GO TO QUESTION 13

10. IF NOT: which one is he? ...............child

12. Are there other children from 0 to 5 year old living in your home? (0) No (1) Yes

13. How many people live in your house? ..........................people.

14. Last month, approximately, what was the total income of people living in your home? dollars (approximate family income)

Now some questions about your child's feeding

15. Was your child exclusively breastfed? (0) No (1) Yes, until ...........years old.

$\frac{15 . \text { Was your child exclusively breastfed? (0) No (1) Yes, until ............years old. }}{16 . \text { Did you offer milk to your child in a baby bottle? (0)No. IF NOT GO TO QUESTION } 18}$

Yes, until the age of........ (2) Yes, I still do.

17. At night, how does your child use/used the baby bottle? (0) He/she use/used it at night

(1) He/she drinks/drank a baby botlle for sleeping? (2) He/she seeps/slept with a baby bottle?

the night?

18. Does your child eat candies, cookies, cake, etc., or drinks soda or jelly juice? (0) No (1)Yes

.

20. Your child sucks/sucked his/her finger (0) No. IF NOT GO TO QUESTION 22

$\begin{array}{ll}\text { (1) Yes, until de age of ...... } & \text { (2) Yes, he/she still sucks }\end{array}$

21. IF YES, how often your child sucks/sucked finger? (1) less than once a day (2) every day, iust during the day (3) every day, usst during the night (4) every day, day and night

22. Your child uses/used a pacifier? (0) No (1) Yes, until the age of

23. IF YES, how often your child uses/used a pacifer? (1) less than once a (2) He/she still uses day (3) every day, ust during the night (4) every day, night and day

Figure 1 - Pre-tested questionnaire.

Data obtained were double-typed on the Epi Info 6.0 software (Centers for Disease Control and Prevention, Atlanta, Georgia, USA). After verification, data were transferred to the Stata 9.0 statistic package. The tests used a $5 \%$ significance level $(\mathrm{p}=0.05)$.

At first, descriptive analyses of the collected data were performed. Chi-square and linear trend tests were used in bivariate analyses to verify the occurrence of associations.

\section{Results}

The sample dropout was $8.9 \%$, which was caused by children unauthorized to participate in the research, those who refused to be examined, and those who were absent from school on examination days although several attempts were made to locate them. A total of 502 children were examined.

The children's average age in the sample was 51.7 months, ranging from 24 to 71 months. Table 1 shows other sample characteristics.
Table 1 - Sample description according to age, gender, type of school, family income, and children's sucking habits. Pelotas, $R S$, Brazil $(n=502)$.

\begin{tabular}{|c|c|c|}
\hline \multicolumn{3}{|l|}{ Variables } \\
\hline Age (months) & & \\
\hline $24-35$ & 39 & 7.8 \\
\hline $36-47$ & 131 & 26.0 \\
\hline $48-59$ & 169 & 33.7 \\
\hline $60-71$ & 163 & 32.5 \\
\hline \multicolumn{3}{|l|}{ Gender } \\
\hline Male & 259 & 51.6 \\
\hline Female & 243 & 48.4 \\
\hline \multicolumn{3}{|l|}{ Type of school } \\
\hline Public & 199 & 39.6 \\
\hline Private & 303 & 60.4 \\
\hline \multicolumn{3}{|l|}{ Family income (quintes) } \\
\hline 1 (Ú\$ 50-200) & 96 & 23.3 \\
\hline $2(\cup \$ 210-300)$ & 65 & 15.8 \\
\hline 3 (U\$ 320-500) & 88 & 21.4 \\
\hline 4 (U\$ 550-1200) & 85 & 20.7 \\
\hline $5(\cup \$ 1400-10000)$ & 78 & 18.8 \\
\hline \multicolumn{3}{|l|}{ Bottle feeding } \\
\hline Never & 47 & 9.8 \\
\hline Previously & 166 & 34.1 \\
\hline Currently & 275 & 56.1 \\
\hline \multicolumn{3}{|l|}{ Pacifier sucking } \\
\hline Never & 205 & 41.8 \\
\hline Previously & 134 & 27.4 \\
\hline Currently & 151 & 30.8 \\
\hline \multicolumn{3}{|l|}{ Thumb sucking } \\
\hline Never & 467 & 95.1 \\
\hline Previously & 6 & 1.2 \\
\hline Currently & 18 & 3.7 \\
\hline
\end{tabular}

\# Highest number of unanswered information was 90 for the family income variable.

The prevalence of malocclusions was $67.5 \%$ in children of the city of Pelotas, RS, Brazil. The most prevalent types of malocclusions included anterior open bite $(33.6 \%)$, deep overbite $(22.3 \%)$, posterior crossbite $(9.8 \%)$ and increased overjet (1.8\%) (Figure 2).

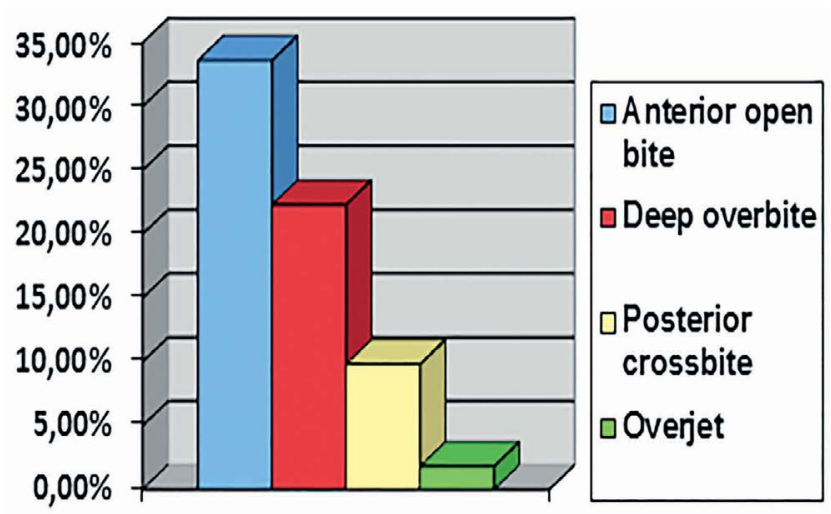

(\%)

Figure 2 - Distribution of types of malocclusion. Pelotas, RS, Brazil.

There was a high prevalence of anterior open bite, showing association with an inverse linear trend regarding children's age and maternal level of education. A direct linear trend was found concerning pacifier use and the duration of use. An association was found between anterior open bite 
and frequency of pacifier use, as well as number of children. There was no association between anterior open bite and thumb sucking or between this malocclusion and family income (Table 2).

Table 2 - Sample description and anterior open bite occurrence according to demographic, socioeconomic, and behavioral variables. Pelotas, $R S$, Brazil $(n=502)$.

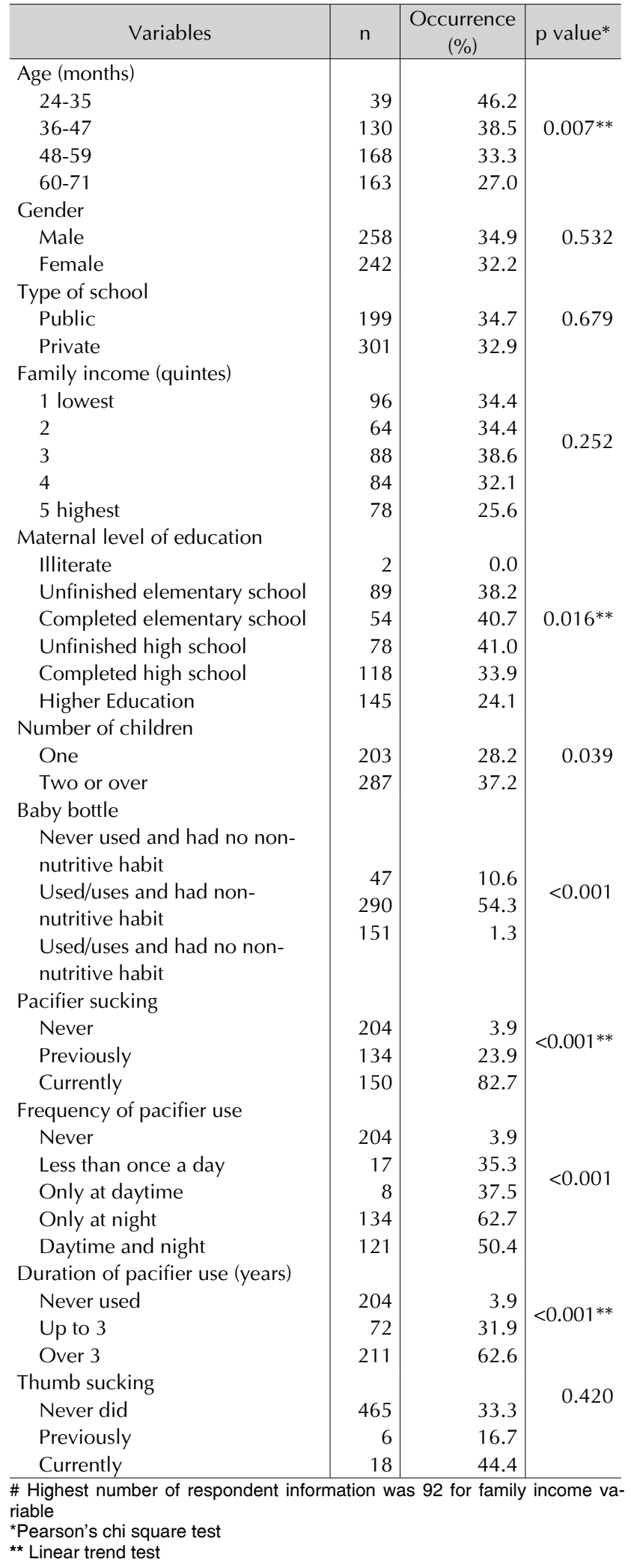

\section{Discussion}

Sample dropout showed similar characteristics to the sample, showing a balance between genders (51\% girls) and a higher frequency of children enrolled in private schools $(77.6 \%)$. The average age was 48.7 months for the dropout and 51.7 months for the sample, showing a proportional ratio. Thus, it is believed the study results did not present any interference as to result occurrence.

Malocclusions have been treated as a public health issue for being a prevalent condition in modern society. ${ }^{4,5,7}$ Therefore, describing and analyzing the occurrence and distribution of malocclusion contribute to offer a solution to public health issues in this area.

Because children with complete primary dentition from both public and private schools were examined, this study may provide an idea of the reality of children in the city of Pelotas, RS, Brazil, considering that a strict methodology was used to maintain the accuracy of results obtained. These results are the basis for the topic of study, whereas they reveal a high malocclusion occurrence among children, agreeing with other literature references. ${ }^{1,4,5,7-9,13,14}$

It is difficult to make a direct comparison to research results in the literature, because there is a great variation in the criteria for evaluation and classification used by researchers and study outlines, in addition to differences among samples such as age, type of dentition, gender, and ethnic groups. ${ }^{4,5,7}$ There are few studies that evaluate primary dentition. Most papers evaluate later periods, and use different tools and verification methods. Moreover, the term "normal occlusion" may be applied to a wide variety of conditions in primary dentition. ${ }^{12}$

The most prevalent types of malocclusion included anterior open bite $(33.6 \%)$, deep overbite $(22.3 \%)$, posterior crossbite $(9.8 \%)$ and increased overjet $(1.8 \%)$. This study found a high prevalence of anterior open bite, similar to other studies in Brazil, such as $36.4 \%^{9}, 46.3 \%^{1,15}$ according to age. This malocclusion presents a significant association to non-nutritive sucking habits. ${ }^{10}$

Deep overbite was found in $19.7 \%{ }^{16}$ of children in another Brazilian study similar to the aforementioned ones. Posterior crossbite was observed in 9.8\%. According to studies, the ranges of frequency of posterior crossbite in the primary dentition are $12.1 \%{ }^{10}, 13.1 \%{ }^{16}$, and $20.81 \% .^{13}$ The majority of studies on posterior crossbite associated these changes with non-nutritive sucking habits. ${ }^{13}$

It was possible to observe that $1.8 \%$ of the children presented increased overjet, unlike other studies carried out with children in Brazil, which found a prevalence of $10.5 \%{ }^{16}$ and $29.7 \% .^{9}$ These results may have occurred due to the difference of methodology used by the authors. 
Anterior open bite was the prevailing type of malocclusion in this study, with a $33.6 \%$ occurrence rate, agreeing with most epidemiological studies found in the literature available, which range from $25.8 \%$ to $66.7 \%$ at age $3{ }^{4,17}$ from $7.1 \%$ to $36.4 \%$ at age $4,{ }^{8-10}$ from $5.3 \%$ to $29 \%$ at age $5,,^{8,10}$ and from $0.9 \%$ to $46.3 \%$ at age $6.1,7,8,15,17$

There was no association of anterior open bite and child gender, corroborating literature findings. ${ }^{1}$ This malocclusion was not associated to type of school and family income either, which justified the non-stratification according to school type in this study.

There was an inverse linear trend between anterior open bite and child's age, suggesting that, as children grow older, there is a tendency to decrease non-nutritive sucking habits and anterior open bite occurrence.

Research has shown that sucking habits are factors that may generate a greater incidence of malocclusions in primary dentition..$^{4,5,9}$ They are also key etiological factors in the occurrence of anterior open bite $^{5,10}$ and posterior crossbite. ${ }^{8}$

There was no association of anterior open bite and thumb sucking, which contradicts other studies that indicate thumb sucking as a risk factor of anterior open bite. ${ }^{1,15}$ This may be justified by the low occurrence of this habit, which caused the sample analyzed to be too small to validate associations with this variable.

Anterior open bite was associated with bottle feeding, whereas children who used the baby bottle and had no non-nutritive sucking habits presented low malocclusion occurrence, suggesting that the use of the bottle alone is not a concerning factor. A similar result was found in the literature in a study showing that the use of the bottle produces less significant changes in occlusion than non-nutritive sucking habits. ${ }^{6}$

Pacifier use showed a direct linear trend in relation to anterior open bite, in agreement with other studies, ${ }^{4,18,19}$ and an association could be equally made with reference to habit duration. There was an association with frequency of use. These findings confirm the importance of duration and frequency of sucking habits in occlusal changes; also, they reveal the deleterious character of non-nutritive sucking habits after age three, considering that up to this age they may be regarded as physiological. ${ }^{5}$ The spontaneous correction of malocclusion occurs once these habits have ceased. ${ }^{10}$

The city of Pelotas showed a high rate of pacifier use, involving about $50-60 \%$ of children ${ }^{1,20}$, agreeing with the present study, which found that $58.2 \%$ of children had used or still uses pacifiers. This is concerning because the pacifier is closely identified with the baby and adds to its image; it also calms babies when they are crying, according to mothers. ${ }^{21}$

Differently from another piece of research studied, ${ }^{1}$ an inverse linear trend association with maternal level of education was found, showing that mothers with higher level of education had children with lower open bite frequency, which suggests these mothers were aware of the deleterious effect of the pacifier sucking habit.

There was also an association between the number of children and anterior open bite, revealing that only children showed a lower occurrence of this malocclusion, which suggests that mothers with the highest number of children have less readiness to provide attention to the child. ${ }^{22}$

The data obtained in this study refer to the population of the city of Pelotas, RS, Brazil. Therefore, studies with other populations and updates should be performed so to provide a correct view of the epidemiology of malocclusions and elaborate effective prevention and intervention actions.

\section{Conclusions}

There was a high prevalence of malocclusions in children in the city of Pelotas, RS, Brazil. Anterior open bite was the most frequent type of malocclusion and was closely associated with the use of pacifier, the duration and frequency of use, and the number of children.

\section{Resumo}

Objetivo: o objetivo deste estudo foi avaliar a ocorrência de más oclusões em crianças com dentição decídua completa, descrevendo a mais frequente e verificando possíveis associações com fatores demográficos, socioeconômicos e comportamentais. Sujeitos e método: foram examinadas 502 crianças com dentição decídua completa de escolas de educação infantil da cidade de Pelotas, RS, Brasil. Os dados coletados foram baseados nos questionários respondidos pelas mães e nos exames físicos da cavidade bucal das crianças. As crianças ditas com más oclusões apresentavam pelo menos uma das seguintes alterações: mordida aberta anterior, sobremordida, mordida cruzada posterior e sobressaliência. Foram utilizados testes de Qui-Quadrado para heterogeneidade e de tendência linear para a verificação das associações com os fatores demográficos, socioeconômicos e comportamentais. Resultados: a ocorrência de más oclusões na população estudada foi de $67,5 \%$. 33,6\% apresentaram mordida aberta anterior, 22,3\% sobremordida, 9,8\% apresentaram mordida cruzada posterior e 1,8\% sobressaliência. A má oclusão mais frequente foi a mordida aberta anterior que apresentou associação direta com o uso da chupeta $(p<0,001)$, com a duração do uso $(p<0,001)$ e com sua frequência $(p<0,001)$, e associação inversa com a idade das crianças $(p=0,007)$ e com a escolaridade materna $(p=0,016)$. Encontrou-se associação entre número de fiIhos e mordida aberta anterior ( $p=0,039)$. Conclusão: a população estudada apresentou alta prevalência de más oclusões e a mordida aberta anterior, que foi a má oclusão mais prevalente, esteve associada ao uso da chupeta e à duração e à frequência do uso dessa.

Palavras-chave: Má oclusão; Dentição; Epidemiologia. 


\section{References}

1. Peres KG, Barros AJD, Peres MA, Victora CG. Effects of breastfeeding and sucking habits on malocclusion in a birth cohort study. Rev Saúde Pública 2007a;41(3):343-350.

2. Proffit WR, Fields H. Ortodontia Contemporânea. 2 ed. Rio de Janeiro: Guanabara Koogan; 1995.

3. Gomes MC, Pinto-Sarmento TCA, Costa EMMB, Martins CC, Granville-Garcia AF, Paiva SM. Impact of oral health conditions on the quality of life of preschool children and their families: a cross-sectional study. Health and Quality of Life Outcomes 2014;12:55.

4. Emmerich AO, Fonseca L, Elias AM, Medeiros UV. The relationship between oral habits, oronasopharyngeal alterations, and malocclusion in preschool children in Vitória, Espírito Santo, Brazil. Cad Saude Publica 2004;20(3):689-697.

5. Tomita NE, Bijela VT, Franco LJ. The relationship between oral habits and malocclusion in preschool children. Rev Saude Publica 2000; 34(3):299-303.

6. Viggiano D, Fasano D, Monaco G, Stohmenger L. Breast feeding, bottle feeding and non-nutritive sucking; effects on occlusion in deciduous dentition. Arch Dis Child 2004;89(12):1121-1123.

7. Frazão P, Narvai PC, Latorre MRDO, Castellanos RA. Are several occlusal problems more frequent in permanent than deciduous dentition? Rev Saude Publica 2004;38(2):247-254.

8. Chevitarese ABA, Della Valle D, Moreira TC. Prevalence of malocclusion in 4-6 year old Brazilian children. J Clin Pediatr Dent 2002;27(1):81-85.

9. Katz CR, Rosemblatt A, Gondim PP. Nonnutritive sucking habits in Brazilian children: effects on deciduous dentition and relationship with facial morphology. Am J Orthod Dentofacial Orthop 2004;126(1):53-57.

10. Katz CR, Rosemblatt A. Nonnutritive sucking habits and anterior open bite in Brazilian children: a longitudinal study. Pediatr Dent 2005;27(5):369-373.

11. World Health Organization. Oral health surveys: basic methods. 4 ed. Geneva: WHO; 1997

12. Foster TD, Hamilton MC. Occlusion in the primary dentition: study of children at $2 \frac{1}{2}$ to 3 years of age. Br Dent J 1969 21;126(2):76-79.

13. Da Silva Filho OG, Santamaria M Jr, Capelozza Filho L. Epidemiology of posterior crossbite in the primary dentition. J Clin Pediatr Dent 2007;32(1):73-78.

14. Leite-Cavalcanti A, Medeiros-Bezerra PK, Moura C. Breast-feeding, bottle-feeding, sucking habits and malocclusion in Brazilian preschool children. Rev Salud Publica 2007;9(2):194-204

15. Peres KG, Oliveira LMR, Sheiham A, Peres MA, Victora CG, Barros FC. Social and biological early life influences on the prevalence of open bite in Brazilian 6-year-olds. Int J Paediatr Dent 2007b;17(1):41-49.

16. Carvalho AC, Paiva SM, Scarpelli AC, Viegas CM, Ferreira FM, Pordeus IA. Prevalence of malocclusion in primary dentition in a population-based sample of Brazilian preschool children. Eur J Paediatr Dent 2011;12(2):107-111.

17. de Vis H, De Boever JA, Van Cauwenberghe P. Epidemiologic survey of functional conditions of the masticatory system in Belgian children aged 3-6 years. Community Dent Oral Epidemiol 1984;12(3):203-207.

18. Zardetto CG, Rodrigues CR, Stefani FM. Effects of different pacifiers on the primary dentition and oral myofunctional structures of preschool children. Pediatr Dent 2002;24(6):552-560.
19. Silvestrini-Biavati A, Salamone S, Silvestrini-Biavati F, Agostino P, Ugolini A. Anterior open-bite and sucking habits in Italian preschool children. Eur J Paediatr Dent 2016;17(1):43-6.

20. Victora CG, Behague DP, Barros FC, Olinto MT, Weiderpass E. Pacifier use and short breastfeeding duration: cause, consequence or coincidence? Pediatrics 1997;99(3):445-453.

21. Sertório SC, Silva IA. The symbolic and utilitarian facets of pacifiers according to mothers. Rev Saude Publica 2005;39(2):156-62

22. Halpern R, Giugliani ERJ, Victora CG, Barros FC, Horta BL. Risk factors for suspicion of developmental delay at 12 months of age. J Pediatr 2000;76:421-428.

\section{Endereço para correspondência:}

Catiara Terra da Costa

Faculdade de Odontologia Universidade Federal de Pelotas

Rua Gonçalves Chaves, 457 Centro

96015-560 Pelotas-RS

Fone: (53) 3225.6741 / (53) 3222.4162

E-mail: catiaraorto@gmail.com

Recebido: 21/07/2016. Aceito: 19/01/2017 